\title{
Brief Communication: Further summer speedup of Jakobshavn Isbræ
}

\author{
I. Joughin ${ }^{1}$, B. E. Smith ${ }^{1}$, D. E. Shean ${ }^{1,2}$, and D. Floricioiu ${ }^{3}$ \\ ${ }^{1}$ Polar Science Center, Applied Physics Lab, University of Washington, 1013 NE 40th St., Seattle, WA 98105-6698, USA \\ ${ }^{2}$ Earth \& Space Sciences, University of Washington, Seattle, WA 98195, USA \\ ${ }^{3}$ German Aerospace Center (DLR), Remote Sensing Technology Institute, SAR Signal Processing, Muenchenerstr. 20, \\ 82230 Wessling, Germany
}

Correspondence to: I. Joughin (ian@apl.washington.edu)

Received: 14 October 2013 - Published in The Cryosphere Discuss.: 15 November 2013

Revised: 15 January 2014 - Accepted: 15 January 2014 - Published: 3 February 2014

\begin{abstract}
We have extended the record of flow speed on Jakobshavn Isbræ through the summer of 2013. These new data reveal large seasonal speedups, 30 to $50 \%$ greater than previous summers. At a point a few kilometres inland from the terminus, the mean annual speed for 2012 is nearly three times as great as that in the mid-1990s, while the peak summer speeds are more than a factor of four greater. These speeds were achieved as the glacier terminus appears to have retreated to the bottom of an over-deepened basin with a depth of $\sim 1300 \mathrm{~m}$ below sea level. The terminus is likely to reach the deepest section of the trough within a few decades, after which it could rapidly retreat to the shallower regions $\sim 50 \mathrm{~km}$ farther upstream, potentially by the end of this century.
\end{abstract}

\section{Introduction}

The speeds of many of Greenland glaciers have varied dramatically over the last two decades (Howat et al., 2008; Moon et al., 2012), which has contributed to the ice sheet's increasingly negative mass imbalance (Rignot and Kanagaratnam, 2006; Shepherd et al., 2012; van den Broeke et al., 2009). Nowhere are such changes more evident than on Greenland's fastest glacier, Jakobshavn Isbræ (Fig. 1), which sped up more than twofold over the last decade and a half (Joughin et al., 2012a). After a period of multi-decadal relative stability (Pelto et al., 1989), speedup began in the late 1990s when Jakobshavn Isbræ's floating ice tongue began to weaken and break up (Joughin et al., 2004; Luckman and
Murray, 2005; Thomas et al., 2003), likely in response to increased basal melting (Holland et al., 2008; Motyka et al., 2011) and to weakened ice mélange in the fjord (Amundson et al., 2010; Joughin et al., 2008). Since the loss of this ice tongue, the glacier's speed has varied, seasonally slowing down with terminus advance in winter and speeding up with terminus retreat in summer (Joughin et al., 2012a). This seasonal variation of the terminus position may be driven by seasonal changes in the rigidity of the ice mélange, which appear to reduce winter calving (Amundson et al., 2010). Over the past several years, the speedup has gradually increased and migrated inland due to a number of feedbacks as the glacier has thinned and retreated (Joughin et al., 2012a; Van der Veen et al., 2011). Largely as a consequence of this speedup, Jakobshavn Isbræ alone has contributed nearly $1 \mathrm{~mm}$ to global sea level over the period from 2000 to 2011 (Howat et al., 2011).

A record of Jakobshavn Isbræ's variation in speed from the mid-1990s through mid-2011 was published recently (Joughin et al., 2012a). Since then, the summer speedups in 2012 and 2013 were in excess of those observed in previous summers. Thus, here we provide an extension to the record of flow speed to include events through 2013.

\section{Results}

Since 2009, we have mapped the speed of Jakobshavn Isbræ regularly using data from the German Space Agency's (DLR) TerraSAR-X synthetic aperture radar (SAR). To do this, we applied a set of well-established speckle-tracking techniques 


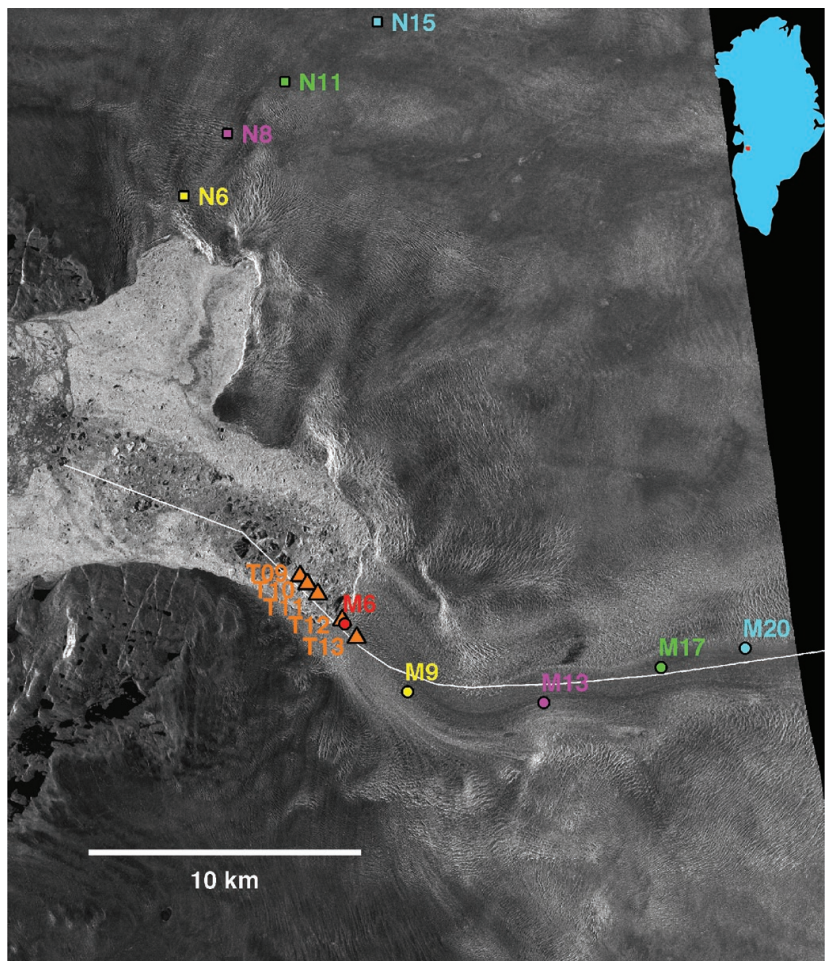

Fig. 1. TerraSAR-X image acquired 20 September when the terminus was near the point of maximum retreat in the summer of 2013. Markers M6-M20 and T09-T13 show the locations of points plotted in Fig. 2. The white profile indicates the location of the profile plotted in Fig. 3. TerraSAR-X image copyright DLR, 2013.

(Joughin, 2002) to pairs of TerraSAR-X images separated by 11 days. Figure 2 shows a time series of speeds extracted from these velocity maps. These speeds typically have slopedependent errors of up to $\sim 3 \%$, which are also a function of the particular imaging geometry. One complication with Jakobshavn Isbræ is that surface elevations near the terminus are lowering rapidly $\left(\sim 15 \mathrm{~m} \mathrm{a}^{-1}\right)$ (Joughin et al., 2008; Krabill et al., 2004), which can increase slope errors and introduce geolocation errors. To reduce such errors, we used an updated digital elevation model (DEM) for each calendar year determined using a combination of ASTER-stereo (Howat et al., 2014), WorldView-stereo, and TanDEM-X elevation data.

The speeds plotted in Fig. 2 are from the locations along the glacier's main trunk that are shown in Fig. 1 (M26 and M43 locations not shown). The coloured circles correspond to fixed points such that the name (e.g. M6) indicates the distance from the late 2003 ice front. Because these points are fixed in space, the changes in speed reflect both the influence of proximity to the terminus and variation in terminus thickness, both of which vary with terminus advance and retreat. To help separate these effects, we also plotted the speed at a point (T09-T13) $1 \mathrm{~km}$ behind the location of where the terminus reaches its point of maximum summer retreat for

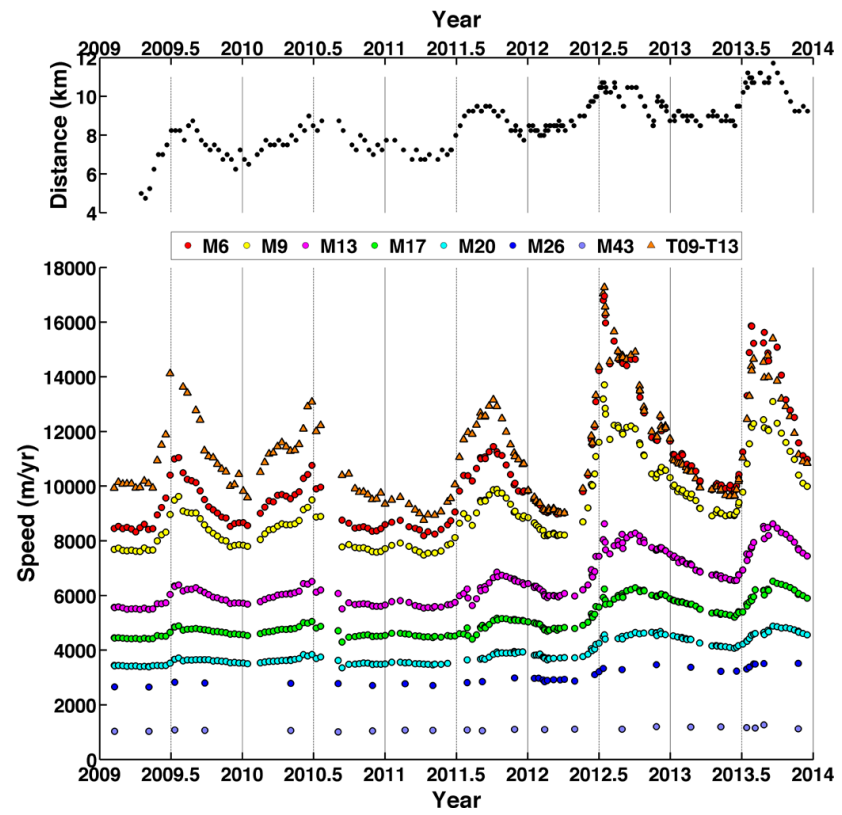

Fig. 2. Plots of (top) terminus position and (bottom) speed through time for Jakobshavn Isbræ determined from TerraSAR-X data collected from 2009 to 2013. Terminus position was digitized where it intersects the white profile shown in Fig. 1. The colour circles (M6-M43) show the speed at several points along the glacier's main trunk at the locations shown in Fig. 1 (M26 and M43 locations not shown; see Joughin et al., 2008). Each point's numerical designation (e.g. M6) gives the approximate distance in kilometres from glacier terminus in late summer 2003 and these points are used for consistency with earlier records (Joughin et al., 2008, 2012b). Additional markers, T09-T13 (orange triangles) (locations shown in Fig. 1), are each situated $1 \mathrm{~km}$ upstream of the terminus at its position of maximum retreat for the years 2009-2013. Each year, speeds are plotted for the corresponding point (T09-T13).

the corresponding calendar year. As a result, speed at these points is largely influenced by near-terminus conditions (e.g. thickness) rather than by diminishing proximity to the terminus.

Figure 2 shows the change in speed on Jakobshavn Isbræ since 2009, extending a satellite-derived record that reaches back to 1992 (see Fig. S1 in the Supplement) (Joughin et al., 2012a). Although our focus is on the main branch, for completeness, Fig. S2 provides a record of variation in speed along the north branch (points N6-N15 in Fig. 1). Following the near doubling of speed near the terminus of the main branch in the late 1990s to early 2000s (Joughin et al., 2004; Luckman and Murray, 2005), Jakobshavn Isbræ sped up more moderately at rates of 2.6-4.4\% per year from 2004 to 2011, coincident with a strong seasonal variation in speed (Joughin et al., 2012a). Our data show that in the last two years this pattern has altered, beginning with the increase in the peak summer speed at M6 by 50\% from 2011 to 2012 (11300 to $17000 \mathrm{~m} \mathrm{a}^{-1}$ ). Some of this change can be attributed to the terminus having a greater influence on speed 
as it moves increasingly close to M6 each summer $(<1 \mathrm{~km}$ in 2013). Just above the terminus (orange triangles Fig. 2), peak speeds increased by $31 \%$ from summer 2011 to 2012 (13 300 to $17100 \mathrm{~m} \mathrm{a}^{-1}$ ). From 2012 to 2013, peak summer speeds near the terminus (M6 \& M9) appear to have declined slightly, but increased at points farther inland (M13-M46). The TerraSAR-X satellite was inoperative for a brief period in early August 2013, so that we missed acquisitions near the time of the 2013 peak. As a result and because the peak in 2012 was brief, we cannot rule out the possibility of a similarly brief peak in 2013 with a similar or even greater magnitude than 2012. The summer 2012 peak at M6 represents a $420 \%$ increase in speed relative to the 1992 value, which corresponds to a period with little observed seasonal variation (Echelmeyer and Harrison, 1990; Pelto et al., 1989). Thus, a more direct comparison is that of the mean annual speed at M6 in $2012\left(11600 \mathrm{~m} \mathrm{a}^{-1}\right)$, which yields a 1992 to 2012 speedup of $286 \%$. Winter near terminus speeds (T9T13) show little increase.

To evaluate terminus retreat, for each TerraSAR-X image, we digitized the location where the terminus intersects the white profile shown in Fig. 1 and plotted the results in Fig. 2 (top). Since there are geolocation errors associated with rapidly changing topography as described above, this yields position errors of $\pm 100 \mathrm{~m}$. While terminus position often appears to influence terminus speed (Howat et al., 2008), of greater importance is whether the terminus is retreating into deeper water (Howat et al., 2005; Thomas, 2004). To examine the relationship of retreat to surface and bed geometry, Fig. 3 illustrates the glacier geometry, corresponding to the white profile shown in Fig. 1, along with the position of the terminus through time. We have aligned this profile to follow the deepest part of the gridded bed map, which differs from the points where we have plotted speeds.

\section{Discussion}

As a terminus with little or no floating extension advances and retreats, its thickness and height above flotation vary. Several studies indicate that this variation exerts a strong influence on speed within several ice thicknesses of the calving front at time scales ranging from minutes to years (Thomas, 2004; Howat et al., 2005; Nettles et al., 2008; Nick et al., 2009; Joughin et al., 2012b). This means that as the terminus retreats into deeper water, the pressure boundary condition at the near-vertical terminus face produces a force that must be balanced upstream by longitudinal stress gradients, which are produced through increased stretching (i.e. speedup). This stretching should produce thinning that contributes to further retreat. In response, additional feedbacks (e.g. evolving driving stress, changes in basal water pressure, and margin softening) contribute to the overall variation in a glacier's speed as its geometry evolves in response (Joughin et al., 2012a; Van der Veen et al., 2011).

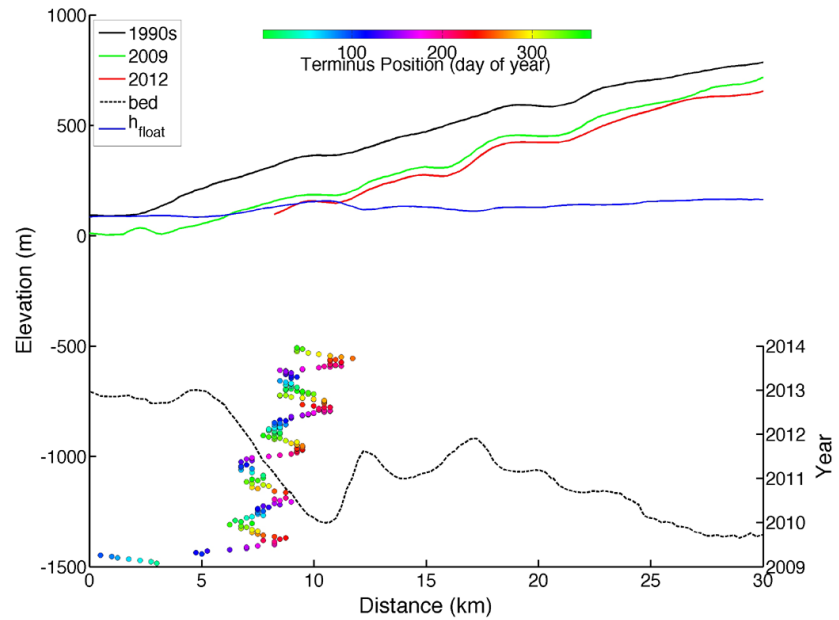

Fig. 3. Surface and bed elevations in the near-terminus region of Jakobshavn Isbræ along the profile shown in Fig. 1. Terminus position ( $x$ axis) is shown as a function of time (right $y$ axis) with colour to indicate day of year (see also same data in Fig. 2). Surface elevations were determined (Joughin et al., 2012a) by interpolating data collected by NASA's Airborne Topographic Mapper (ATM) in the 1990s, 2009, and 2012 as part of Operation IceBridge and its predecessor missions (Krabill et al., 2004). Bed elevations were interpolated from a gridded map of radar depth soundings produced by the Center for Remote Sensing of Ice Sheets (CReSIS)(Li, 2009; Van der Veen et al., 2011). Multiple versions of the DEM exist, but based on comparison with other data sets our preferred version is the one located at (ftp://data.cresis.ku.edu/data/grids/old_format/2008_ Jakobshavn.zip).

Analysis of data from 2009 indicates that the forces associated with the terminus depth variation and height above flotation account for most of Jakobshavn Isbræ's seasonal flow variation (Joughin et al., 2012a). Such results are consistent with the large summer speedups in 2012 and 2013 when the terminus appears to have reached the bottom of an overdeepened basin (Fig. 3), which occurred after the terminus retreated more than a kilometre farther inland than previous summers. While the correspondence between seasonally varying terminus position and speed is relatively strong, there are some notable differences. For instance, peaks in speed tend to be sharper in time than corresponding peaks in terminus retreat, which, in addition to the nonlinearity of the ice dynamics, likely reflects the glacier's rapid evolution. As an example, if the terminus maintains roughly the same location for a period of weeks (e.g. relatively flat peak in late summer 2011), then the terminus should continue to thin by several metres over the same period. Since speed is sensitive to height above flotation, this thinning is likely to reduce the peak speed even with no change in terminus position.

Over the $5 \mathrm{yr}$ period of our observations, the correspondence between terminus depth and speed is less clear. The greatest mean annual speeds do occur in 2012 when the terminus is near what appears to be an overdeepening and 
subsequently decline in 2013 as the terminus retreats to higher ground. By contrast, the 2009 mean speed was faster $\left(11130 \mathrm{~m} \mathrm{a}^{-1}\right)$ than the $2011\left(10590 \mathrm{~m} \mathrm{a}^{-1}\right)$, despite a more advanced 2009 terminus position. This difference likely reflects the fact that at these time scales, the other processes and feedbacks mentioned above have a substantial influence on flow (Joughin et al., 2012a; Van der Veen et al., 2011).

If Jakobshavn Isbræ's terminus has reached the bottom of an overdeepened region, then the terminus may be able to find a position of transient stability on the high spot farther upstream (located at $\sim 12$ to $17 \mathrm{~km}$ in Fig. 3) as retreat to shallower depths yields slower speeds (Joughin et al., 2012a). The relatively high surface slope region above the basin, where the present heights are tens to hundreds of metres above flotation, may further slow retreat, since it should take more time to thin to near flotation. By contrast, low surface slopes and heights near flotation (Fig. 3) likely facilitated the rapid retreat since 2009. While the high spot above the basin may slow flow, the terminus would still be grounded on a bed at least $900 \mathrm{~m}$ below sea level, likely yielding speeds well above balance that would maintain strong, although potentially diminished, thinning. As a consequence, the terminus likely will continue to retreat, albeit perhaps more slowly in the near term, until it again reaches bed depths similar to summer $2012(\sim 1300 \mathrm{~m}$ below sea level $)$ at $\sim 15 \mathrm{~km}$ farther upstream (Fig. 3). As the large drawdown since the 1990s indicates, such a retreat could happen over the span of a few decades or less (Joughin et al., 2012a). At the current stage, further retreat may largely be driven by ice dynamics with only weak coupling to climate forcing. Thus, a re-advance rather than retreat likely would require a period of extended (several years to decades) cooling.

Once past the high spot, the trough extends roughly $50 \mathrm{~km}$ farther inland at depths below sea level of $\sim 1200 \mathrm{~m}$ and greater before eventually reaching shallower depths. Thus, although there is some variation in trough width $(\sim 3.5$ to $5.5 \mathrm{~km})$ that could modulate the rate of flow, once into this deepest part of the trough, extreme velocities $\left(>12000 \mathrm{~m} \mathrm{a}^{-1}\right)$ are likely to persist as the terminus rapidly retreats (Thomas et al., 2011). Furthermore, without the ability to seasonally advance up a relatively steep bed slope as in the past several winters, such high speeds may be sustained year round. Because the deep trough of Jakobshavn is extremely difficult to measure with conventional techniques (Li, 2009), we cannot rule out that some or all of the high spot might be a gridding artifact, in which case retreat may occur even more rapidly. Similarly, we cannot rule out that some bed highs may not have been resolved that could provide additional points of transient stability.

The transient summer speeds we observe for 2012 (> $17000 \mathrm{~m} \mathrm{a}^{-1}$ ) appear to represent the fastest observed speed for any outlet glacier or ice stream in Greenland or Antarctica. This yields a transient peak speed a factor of four greater than the speeds observed in the 1990s, while the mean annual speedup is by just under a factor of three. If, as the glacier recedes up the trough, it is able to maintain the peak speeds year round, then a sustained speedup of the terminus by a factor of four or five is conceivable based on recent behaviour, which is about half of the nominal tenfold upper limit on the amount a glacier could speed up by that was proposed by Pfeffer et al. (2008). Nevertheless, these speeds would occur in a trough roughly twice as deep as prior to the speedup. Hence, a tenfold increase in ice flux may be possible for Jakobshavn Isbræ if the trough does not narrow substantially with distance upstream. Equivalently, while the increase in terminus speed and the glacier's overall maximum speed may remain under a factor of five, as the terminus retreats farther inland where the speeds now are comparatively slow, the relative speedup is much greater (e.g. if the terminus retreated to M26 with a speed of $16000 \mathrm{~m} \mathrm{a}^{-1}$, this would represent a twelvefold speedup). Thinning by hundreds of metres to a terminus near flotation, however, would yield something closer to a tenfold flux increase $(\sim 8.5$ based on simple scaling by the ratio of thickness at flotation to thickness in 1990s). It is unlikely that such retreat could be sustained for more than a few decades because the terminus would rapidly retreat $\sim 50 \mathrm{~km}$ to shallower depths (Joughin et al., 2012a).

\section{Conclusions}

Our results show that Jakobshavn Isbræ has accelerated to speeds unprecedented in its observational record as its terminus has retreated to a region where the bed is $\sim 1300 \mathrm{~m}$ below sea level. While the current increase in annual discharge flux remains less than a factor of three, the increase plausibly could reach or exceed a factor of 10 within decades. This is a consequence of the fact that retreat into deeper water increases both speed and thickness of the terminus. Conversely, where retreat to shallower depths occurs, losses will be far more moderate. Hence, a tenfold increase in discharge is likely only to be sustained in the few decades before rapid thinning would cause the terminus to retreat out of the deep trough. Thus, the potential for large losses from Greenland is likely to be determined by the depth and inland extent of the troughs through which its outlet glaciers drain. These features are only beginning to be well resolved by international efforts such as NASA's Operation IceBridge. The relatively sparse data collected thus far indicate that, with its great depths and inland extent, Jakobshavn's Isbræ is somewhat unique (Bamber et al., 2013), suggesting that it may be difficult for the majority of Greenland's outlet glaciers to produce or to sustain such large increases in ice discharge.

\section{Supplementary material related to this article is available online at http://www.the-cryosphere.net/8/209/ 2014/tc-8-209-2014-supplement.pdf.}


Acknowledgements. The contribution to this work by I. Joughin was supported National Science Foundations Office of Polar Programs (NSF-OPP) through the Center for Remote Sensing of Ice Sheets (CReSIS) (NSF ANT-0424589). The National Aeronautics and Space Administration's (NASA) Earth Science Division (NNX09AE47G) supported the contribution to this work by B. E. Smith. Support for the SAR data processing was from NASA's MEaSUREs Program (NNX08AL98A and NNX13AI21A). The TerraSAR-X and TanDEM-X data were provided by the German Space Agency (DLR), project HYD0754 and XTI_GLAC0400. The bed elevation data were provided by CRESIS and the surface elevation data were provided by NASA's Airborne Topographic Mapper (ATM) Program. NASA's Operation IceBridge and its predecessor campaigns provided the instrument platform for both the bed and elevation data collection. Comments by J. Bamber, P. Christoffersen, A. Luckman, M. Maki, M. Pelto, and an anonymous reviewer improved the revised manuscript.

Edited by: J. L. Bamber

\section{References}

Amundson, J. M., Fahnestock, M., Truffer, M., Brown, J., Luethi, M. P., and Motyka, R. J.: Ice melange dynamics and implications for terminus stability, Jakobshavn Isbrae Greenland, J. Geophys. Res.-Earth, 115, F01005, doi:10.1029/2009JF001405, 2010.

Bamber, J. L., Griggs, J. A., Hurkmans, R. T. W. L., Dowdeswell, J. A., Gogineni, S. P., Howat, I., Mouginot, J., Paden, J., Palmer, S., Rignot, E., and Steinhage, D.: A new bed elevation dataset for Greenland, The Cryosphere, 7, 499-510, doi:10.5194/tc-7499-2013, 2013.

Echelmeyer, K. and Harrison, W. D.: Jakobshavns Isbræ, West Greenland: Seasonal variations in velocity-or lack thereof, J. Glaciol., 36, 82-88, 1990.

Holland, D. M., Thomas, R. H., De Young, B., Ribergaard, M. H., and Lyberth, B.: Acceleration of Jakobshavn Isbrae triggered by warm subsurface ocean waters, Nat. Geosci., 1, 659-664, doi:10.1038/ngeo316, 2008.

Howat, I. M., Joughin, I., Tulaczyk, S., and Gogineni, S.: Rapid retreat and acceleration of Helheim Glacier, east Greenland, Geophys. Res. Lett., 32, L22502, doi:10.1029/2005GL024737, 2005.

Howat, I. M., Joughin, I., Fahnestock, M., Smith, B. E., and Scambos, T. A.: Synchronous retreat and acceleration of southeast Greenland outlet glaciers 2000-06: ice dynamics and coupling to climate, J. Glaciol., 54, 646-660, doi:10.3189/002214308786570908, 2008.

Howat, I. M., Ahn, Y., Joughin, I., Van Den Broeke, M. R., Lenaerts, J. T. M., and Smith, B.: Mass balance of Greenland's three largest outlet glaciers, 2000-2010, Geophys. Res. Lett., 38, L12501, doi:10.1029/2011GL047565, 2011.

Howat, I. M., Negrete, A., and Smith, B. E.: The Greenland Ice Mapping Project (GIMP) land classification and surface elevation datasets, The Cryosphere Discuss., 8, 453-478, doi:10.5194/tcd-8-453-2014, 2014.

Joughin, I.: Ice-sheet velocity mapping: A combined interferometric and speckle-tracking approach, Ann. Glaciol., 34, 195-201, 2002 .
Joughin, I., Abdalati, W., and Fahnestock, M.: Large fluctuations in speed on Greenland's Jakobshavn Isbræ glacier, Nature, 432, 608-610, doi:10.1038/nature03130, 2004.

Joughin, I., Howat, I. M., Fahnestock, M., Smith, B., Krabill, W., Alley, R. B., Stern, H., and Truffer, M.: Continued evolution of Jakobshavn Isbrae following its rapid speedup, J. Geophys. Res.Earth, 113, F04006, doi:10.1029/2008JF001023, 2008.

Joughin, I., Smith, B. E., Howat, I. M., Floricioiu, D., Alley, R. B., Truffer, M., and Fahnestock, M.: Seasonal to decadal scale variations in the surface velocity of Jakobshavn Isbrae, Greenland: Observation and model-based analysis, J. Geophys. Res., 117, F02030, doi:10.1029/2011JF002110, 2012a.

Joughin, I., Alley, R. B., and Holland, D. M.: Ice-sheet response to oceanic forcing, Science, 338, 1172-1176, doi:10.1126/science.1226481, 2012b.

Krabill, W., Hanna, E., Huybrechts, P., Abdalati, W., Cappelen, J., Csatho, B., Frederick, E., Manizade, S., Martin, C., Sonntag, J., Swift, R., Thomas, R., and Yungel, J.: Greenland Ice Sheet: Increased coastal thinning, Geophys. Res. Lett., 31, L24402, doi:10.1029/2004GL021533, 2004.

Li, J.: Mapping of ice sheet deep layers and fast outlet glaciers with multi-channel-high-sensitivity radar, University of Kansas, Lawrence, 2009.

Luckman, A. and Murray, T.: Seasonal variation in velocity before retreat of Jakobshavn Isbrae, Greenland, Geophys Res Lett, 32, L08501, doi:10.1029/2005GL022519, 2005.

Moon, T., Joughin, I., Smith, B., and Howat, I.: 21st-Century evolution of Greenland outlet glacier velocities, Science, 336, 576578, doi:10.1126/science.1219985, 2012.

Motyka, R. J., Truffer, M., Fahnestock, M., Mortensen, J., Rysgaard, S., and Howat, I.: Submarine melting of the 1985 Jakobshavn Isbrae floating tongue and the triggering of the current retreat, J. Geophys. Res.-Earth, 116, F01007, doi:10.1029/2009JF001632, 2011.

Nettles, M., Larsen, T. B., Elósegui, P., and Hamilton, G. S.: Stepwise changes in glacier flow speed coincide with calving and glacial earthquakes at Helheim Glacier, Greenland, Geophys. Res. Lett, 35, L24503, doi:10.1029/2008GL036127, 2008.

Nick, F. M., Vieli, A., Howat, I. M., and Joughin, I.: Large-scale changes in Greenland outlet glacier dynamics triggered at the terminus, Nat. Geosci., 2, 110-114, doi:10.1038/NGEO394, 2009.

Pelto, M. S., Hughes, T. J., and Brecher, H. H.: Equilibrium state of Jakobshavns Isbræ, West Greenland, Ann. Glaciol., 1989.

Pfeffer, W. T., Harper, J. T., and O'Neel, S.: Kinematic constraints on glacier contributions to 21 st-century sea-level rise, Science, 321, 1340-1343, doi:10.1126/science.1159099, 2008.

Rignot, E. and Kanagaratnam, P.: Changes in the velocity structure of the Greenland ice sheet, Science, 311, 986-990, doi:10.1126/science.1121381, 2006.

Shepherd, A., Ivins, E. R., Geruo, A., Barletta, V. R., Bentley, M. J., Bettadpur, S., Briggs, K. H., Bromwich, D. H., Forsberg, R., Galin, N., Horwath, M., Jacobs, S. S., Joughin, I., King, M. A., Lenaerts, J. T. M., Li, J., Ligtenberg, S. R. M., Luckman, A., Luthcke, S. B., McMillan, M., Meister, R., Milne, G., Mouginot, J., Muir, A., Nicolas, J. P., Paden, J., Payne, A. J., Pritchard, H., Rignot, E., Rott, H., Sørensen, L. S., Scambos, T. A., Scheuchl, B., Schrama, E. J. O., Smith, B., Sundal, A. V., van Angelen, J. H., van de Berg, W. J., van den Broeke, M. R., Vaughan, D. G., Velicogna, I., Wahr, J., Whitehouse, P. L., Wing- 
ham, D. J., Yi, D., Young, D., and Zwally, H. J.: A reconciled estimate of ice-sheet mass balance, Science, 338, 1183-1189, doi:10.1126/science.1228102, 2012.

Thomas, R. H.: Force-perturbation analysis of recent thinning and acceleration of Jakobshavn Isbræ, Greenland, J. Glaciol., 50, 5766, 2004.

Thomas, R. H., Abdalati, W., Frederick, E., Krabill, W., Manizade, S., and Steffen, K.: Investigation of surface melting and dynamic thinning on Jakobshavn Isbrae, Greenland, J. Glaciol., 49, 231239, 2003.

Thomas, R., Frederick, E., Li, J., Krabill, W., Manizade, S., Paden, J., Sonntag, J., Swift, R., and Yungel, J.: Accelerating ice loss from the fastest Greenland and Antarctic glaciers, Geophys. Res. Lett., 38, L10502, doi:10.1029/2011GL047304, 2011. van den Broeke, M., Bamber, J., Ettema, J., Rignot, E., Schrama, E., van de Berg, W. J., van Meijgaard, E., Velicogna, I., and Wouters, B.: Partitioning recent Greenland mass loss, Science, 326, 984 986, doi:10.1126/science.1178176, 2009.

Van der Veen, C. J., Plummer, J. C., and Stearns, L. A.: Controls on the recent speed-up of Jakobshavn Isbrae, West Greenland, J. Glaciol., 57, 770-782, 2011.

Weertman, J.: Stability of the junction of an ice sheet and an ice shelf, J. Glaciol., 13, 3-11, 1974. 